УДК 582.736:577.19:633.88

\title{
БИОЛОГИЧЕСКИ АКТИВНЫЕ ВЕЩЕСТВА ЛИСТЬЕВ LATHYRUS
}

\section{VERNUS}

\section{(C) И.Е. Лобанова}

\author{
Центральный сибирский ботанический сад СО РАН, ул. Золотодолинская, \\ 101, Новосибирск, 630090 (Россия), e-mail: irevlob@ngs.ru
}

\begin{abstract}
Представлены данные по фитохимической оценке содержания флавоноидов, сапонинов, танинов и наличию кумаринов в листьях Lathyrus vernus (чина весенняя) из ценопопуляций лесостепной зоны Западной Сибири в вегетационный период 2009 г. В начале вегетации было отмечено максимальное количество сапонинов, в фазе цветения - флавонолов, а в конце плодоношения - максимум катехинов и танинов. Кумарины отсутствовали в листьях чины весенней в течение всего вегетационного периода. Результаты данного исследования могут быть использованы при более углубленном исследовании Lathyrus vernus в качестве лекарственного сырья.

Ключевые слова: Lathyrus vernus, флавоноиды, сапонины, танины, кумарины.
\end{abstract}

Lathyrus vernus (L.) Bernh. (=Orobus vernus L.) (чина весенняя, сочевичник весенний) не является официнальным растением, но используется в народной медицине при стенокардии, заболеваниях нервной системы, в качестве гемостатического и диуретического [1], обезболивающего и ранозаживляющего [2] средства, улучшает зрение при глаукоме, понижая внутриглазное давление [3]. Спектр биологической активности чины весенней обусловливают соединения различной химической природы: незаменимые аминокислоты, витамины, флавоноиды [4]. В листьях чины весенней был обнаружен 3-софорозид-7-гликозид кемпферола; в стеблях и листьях - циклитолы [5]. Для растений этого вида европейского ареала даны рекомендации по использованию в качестве источника сырья, богатого макро- и микроэлементами, особенно $\mathrm{Fe}, \mathrm{Cu}, \mathrm{Zn}, \mathrm{Mn}$ [5]. По нашим данным, в условиях лесостепной зоны Западной Сибири в листьях Lathyrus vernus в течение вегетационного периода концентрировались $\mathrm{Mo}, \mathrm{Zn}, \mathrm{Br}, \mathrm{Nb}, \mathrm{Sr}, \mathrm{Cu}, \mathrm{Ni}$ [6].

Цель данной работы - определить количественное содержание флавоноидов, сапонинов, танинов и наличие кумаринов в листьях чины весенней, произрастающей в условиях лесостепной зоны Западной Сибири в течение вегетационного периода.

В листьях чины весенней определяли содержание флавоноидов (флавонолов и катехинов), сапонинов, танинов (в процентах от массы воздушно-сухого сырья) и проводили оценку присутствия кумаринов. Флавонолы [7] и катехины [8] определяли спектрофотометрическим методом. Количество сапонинов (сырой сапонин) - весовым методом [9], а танины - титриметрическим [10]. Присутствие кумаринов определяли по интенсивности флюоресценции ортокумариновой кислоты в ультрафиолете [11].

Образцы листьев Lathyrus vernus из ценопопуляций в окрестностях Новосибирска были собраны в течение вегетационного периода 2009 г. по фазам развития: начало вегетации, цветение, начало плодоношения и конец плодоношения.

В течение всего вегетационного периода присутствовали флавонолы, катехины, сапонины и танины, но не были обнаружены кумарины. Содержание веществ в листьях различалось по фазам вегетации. В фазе начала вегетации накапливалось максимальное количество сапонинов (более 3\%), далее, до конца плодоношения, оно сохранялось на уровне $2 \%$. В фазе цветения отмечено максимальное содержание флавонолов. В завершающий период вегетации, в фазе окончания плодоношения, было обнаружено максимальное количество катехинов и танинов. Содержание катехинов на протяжении всего вегетационного периода ме-

Лобанова Ирина Евгеньевна - кандидат биологических наук, тел.: (383) 330-41-01, e-mail: irevlob@ngs.ru нялось незначительно. Содержание танинов увеличивалось, а сапонинов - уменьшалось от начала вегетации к концу плодоношения. 
Содержание биологически активных веществ в листьях чины весенней по фазам ее развития (процент от массы воздушно-сухого сырья)

\begin{tabular}{c|c|c|c|c}
\hline БАВ & $\begin{array}{c}\text { Начало } \\
\text { вегетации }\end{array}$ & Цветение & $\begin{array}{c}\text { Начало } \\
\text { плодоношения }\end{array}$ & $\begin{array}{c}\text { Конец } \\
\text { плодоношения }\end{array}$ \\
\hline Флавонолы & 0,52 & 2,22 & 2,03 & 1,59 \\
Катехины & 0,15 & 0,16 & 0,17 & 0,22 \\
Сапонины & 3,39 & 2,25 & 2,25 & 2,12 \\
Танины & 0,72 & 0,90 & 1,46 & 1,61 \\
Кумарины & - & - & - & - \\
\hline
\end{tabular}

Примечания: «-»- не обнаружены

Минимальные значения флавоноидов и танинов были обнаружены в начале вегетационного периода, а сапонинов - в конце. Содержание катехинов, сапонинов и танинов в листьях чины весенней было определено впервые.

Таким образом, в листьях чины весенней, произрастающей в условиях лесостепной зоны Западной Сибири в течение всего вегетационного периода были обнаружены флавонолы $(0,52-2,22 \%)$, катехины $(0,15-0,22 \%)$, сапонины $(2,12-3,39 \%)$, танины $(0,72-1,61 \%)$. Кумарины отсутствовали. Максимальные количества сапонинов и флавонолов отмечены в первую половину вегетации, а катехинов и танинов - во вторую, в конце плодоношения. Результаты данного исследования могут быть использованы при более углубленном исследовании Lathyrus vernus в качестве лекарственного сырья.

\section{Список литературы:}

1. Растительные ресурсы СССР: Цветковые растения, их химический состав, использование; Семейства Hydrangeaceae-Haloragaceae. Л., 1987. $326 \mathrm{c}$.

2. Кьосев П.А. Полный справочник лекарственных растений. М., 2000. 992 с.

3. Суханов Н.В. Целебные снадобья // «Вера»«Эском». Сыктывкар. 2003. №439. 16 с.

4. Зайчикова С.Г., Самылина И.А., Новожилова Т.И. Изучение липидного и флавоноидного состава образцов некоторых видов рода чина (Lathyrus) // Химико-фармацевтический журнал. 2001. Т. 35, №5. С. 36-38.

5. Зайчикова С.Г., Самылина И.А., Бурляева М.О. Белковый, аминокислотный и минеральный состав отдельных представителей рода чина // Химико-фармацевтический журнал. 2001. Т. 35, №6. С. 51-53.

6. Лобанова И. Е., Чанкина О. В. Элементный состав чины весенней (Lathyrus vernus) // Растительный мир Азиатской России. 2012. №2 (10). С. 56-61.

7. Беликов В.В., Шрайбер М.С. Методы анализа флавоноидных соединений // Фармация. 1970. №1. С. 66-72.

8. Кукушкина Т.А., Зыков А.А., Обухова Л.А. Манжетка обыкновенная (Alchemilla vulgaris L.) как источник лекарственных средств // Актуальные проблемы создания новых лекарственных препаратов природного происхождения: материалы VII междунар. съезда. СПб.; Пушкин, 2003. С. 64-69.

9. Киселева А.В., Волхонская Т.А., Киселев В.Е. Биологически активные вещества лекарственных растений Южной Сибири. Новосибирск. 1991. 136 с.

10. Государственная Фармакопея СССР. 11-е изд. Вып. 1. М., 1987. 816 с.

11. Ермаков А.И, Арасимович В.В., Ярош Н.П., Перуанский Ю.В., Луковникова Г.А., Иконникова М.И. Методы биохимического исследования растений. Л., 1987. 430 с.

Поступило в редакцฺию 3 марта 2014 г.

После переработки 28 марта 2014 г. 
Lobanova I.E. THE BIOLOGICALLY ACTIVE SUBSTANCES IN THE LATHYRUS VERNUS LEAVES

Federal State Budgetary Establishment of Science is the Central siberian botanical garden, SB of RAS, Novosibirsk, Zolotodolinskaya st., 101, 630090 (Russia),e-mail: irevlob@ngs.ru

Data of phytochemical estimation on the maintenance of flavonoids, saponins, tannins and to availability of coumarins in Lathyrus vernus L. leaves from growing populations of forest-steppe area of Western Siberia (vegetation period 2009 year) are represented. In the phase of beginning of vegetation the maximum quantity saponins are collected, in the phase of blossoming - flavonols and at the end of fruiting - the maximum of catechins and tannins was marked. Coumarins in the leaves during the all vegetative period were not absent. Results of this research can be used for more profound studying of Lathyrus vernus as the medicinal raw materials.

Keywords: Lathyrus vernus, flavonoids, saponines, tannins, coumarins

\section{References}

1. Rastitel'nye resursy SSSR: Tsvetkovye rasteniia, ikh khimicheskii sostav, ispol'zovanie; Semeistva Hydrangeaceae Haloragaceae. [Plant resources of the USSR: Flowering plants, their chemical composition and utilization; Family Hydrangeaceae-Haloragaceae]. Leningrad, 1987, 326 p. (in Russ.).

2. K'osev P.A. Polnyi spravochnik lekarstvennykh rastenii. [Complete directory of medicinal plants]. Moscow, 2000, 992 p. (in Russ.).

3. Sukhanov N.V. «Vera»-«Eskom», Syktyvkar, 2003, no. 439, 16 p. (in Russ.).

4. Zaichikova S.G., Samylina I.A., Novozhilova T.I. Khimiko-farmatsevticheskii zhurnal, 2001, vol. 35, no. 5, pp. 3638. (in Russ.).

5. Zaichikova S.G., Samylina I.A., Burliaeva M.O. Khimiko-farmatsevticheskii zhurnal, 2001, vol. 35, no. 6, pp. 51-53. (in Russ.).

6. Lobanova I.E., Chankina O.V. Rastitel'nyi mir Aziatskoi Rossii, 2012, no. 2(10), pp. 56-61. (in Russ.).

7. Belikov V.V., Shraiber M.S. Farmatsiia, 1970, no. 1, pp. 66-72. (in Russ.).

8. Kukushkina T.A., Zykov A.A., Obukhova L.A. Aktual'nye problemy sozdaniia novykh lekarstvennykh preparatov prirodnogo proiskhozhdeniia: materialy VII mezhdunar. s"ezda. [Actual problems of creating new drugs of natural origin: Proceedings of the VII International Congress]. Sankt-Petersburg; Pushkin, 2003, pp. 64-69. (in Russ.).

9. Kiseleva A.V., Volkhonskaia T.A., Kiselev V.E. Biologicheski aktivnye veshchestva lekarstvennykh rastenii Iuzhnoi Sibiri. [Biologically active substances of medicinal plants of southern Siberia]. Novosibirsk, 1991, 136 p. (in Russ.).

10. Gosudarstvennaia Farmakopeia SSSR. [State Pharmacopoeia of the USSR]. 11 ed. Moscow, 1987, no. 1, 816 p. (in Russ.).

11. Ermakov A.I, Arasimovich V.V., Iarosh N.P., Peruanskii Iu.V., Lukovnikova G.A., Ikonnikova M.I. Metody biokhimicheskogo issledovaniia rastenii. [Methods of biochemical research of plants]. Leningrad, 1987, 430 p. (in Russ.).

Received March 3, 2014

Revised March 28, 2014 
